\title{
Logopedia wobec wyzwań i zagrożeń XXI wieku Łódź, 14 października 2017 r. (sprawozdanie z konferencji naukowej)
}

W dniu 14 października 2017 roku w Łodzi odbyła się konferencja naukowa pt. Logopedia wobec wyzwań i zagrożeń XXI wieku, zorganizowana przez Zakład Dialektologii Polskiej i Logopedii Uniwersytetu Łódzkiego. Obrady odbywały się w gmachu Wydziału Filologicznego UŁ przy ul. Pomorskiej 171/173. Honorowy patronat nad konferencją objęli: Jego Magnificencja Rektor Uniwersytetu Łódzkiego prof. dr hab. Antoni Różalski oraz Prezydent Miasta Łodzi Hanna Zdanowska. Patronat medialny sprawowali: TVP3 Łódź, Radio Łódź oraz Radio Parada.

Konferencję otworzyli: prorektor ds. studenckich dr hab. prof. UŁ Tomasz Cieślak, dyrektor Instytutu Filologii Polskiej i Logopedii dr hab. Danuta Kowalska oraz kierownik Zakładu Dialektologii Polskiej i Logopedii dr hab. prof. UŁ Irena Jaros. Podczas inaugurujących wystąpień zwrócili uwagę na prężny rozwój łódzkiej logopedii, która podczas konferencji i seminariów integruje środowiska logopedyczne z całej Polski i w znaczącym stopniu przyczynia się do rozwoju młodych naukowców i studentów.

Celem interdyscyplinarnej konferencji Logopedia wobec wyzwań i zagrożeń $X X I$ wieku było zwrócenie uwagi na nowe zadania stawiane przed współczesną logopedią. Rosnąca liczba osób z zaburzeniami mowy i głosu - dzieci, młodzieży, dorosłych, $w$ tym seniorów - sprawia, że istnieje potrzeba wymiany poglądów na temat

* Zakład Dialektologii Polskiej i Logopedii, Instytut Filologii Polskiej i Logopedii, Wydział Filologiczny Uniwersytetu Łódzkiego, ul. Pomorska 171/173, 90-236 Łódź, e-mail: monika.kazmierczak@ uni.lodz.pl. 
pożądanych kierunków jej rozwoju, $\mathrm{z}$ udziałem naukowców reprezentujących różne ośrodki badawcze, praktyków oraz przedstawicieli dyscyplin współpracujących z logopedami w procesie diagnozy i terapii pacjentów z zaburzeniami mowy. Konferencja była okazją do naukowego dyskursu o redefinicji pojęć funkcjonujących w logopedii i naukach pokrewnych, do przedstawienia najnowszych wyników badań nad komunikacją językową, jej uwarunkowaniami oraz zaburzeniami.

Spotkanie zgromadziło ponad stu uczestników, wśród których znaleźli się przedstawiciele różnych ośrodków naukowych i badawczych oraz praktycy - logopedzi, lekarze, psycholodzy, pedagodzy, nauczyciele wychowania przedszkolnego i języka polskiego, a także liczna grupa studentów logopedii. Podczas konferencji przedstawiciele dziewięciu ośrodków akademickich: Uniwersytetu Zielonogórskiego, Uniwersytetu Kazimierza Wielkiego w Bydgoszczy, Uniwersytetu Pedagogicznego im. KEN w Krakowie, Uniwersytetu Marii Curie-Skłodowskiej w Lublinie, Uniwersytetu Adama Mickiewicza w Poznaniu, Uniwersytetu Warszawskiego, Akademii Pedagogiki Specjalnej im. M. Grzegorzewskiej w Warszawie, Uniwersytetu Medycznego w Łodzi, Uniwersytetu Łódzkiego, a także Wielkopolskiego Centrum Onkologii w Poznaniu wygłosili 26 referatów. Co niezwykle cenne, zarówno w czasie obrad plenarnych, jak i w sekcjach, referenci prezentowali różne spojrzenia na problemy i wyzwania współczesnej logopedii.

W inaugurującym obrady plenarne wystąpieniu dr hab., prof. UZ Ewa Małgorzata Skorek omówiła dwa przeciwstawne podejścia paradygmatyczne obecne w polskiej logopedii: wynikające z paradygmatu biomedycznego oraz z paradygmatu holistyczno-socjo-ekologicznego, oraz ich konsekwencje dla teorii, badań naukowych i praktyki logopedycznej. Następnie prof. dr hab. n. med. Jurek Olszewski (UŁ) przedstawił ocenę parametrów analizy akustycznej i wydolnościowej głosu u studentów kierunku fizjoterapia, z wykorzystaniem nowego programu Diagno Scope Specjalista. Z kolei dr hab. prof. UŁ Danuta Pluta-Wojciechowska wskazywała możliwe źródła inspiracji w ustalaniu sekwencji terapii głosek w dyslalii obwodowej, a dr hab. prof. UKW Dorota Podgórska-Jachnik zaprezentowała model holistycznego wsparcia ucznia $\mathrm{z}$ afazją w edukacji włączającej, z kluczową rolą logopedy w tym zakresie.

W drugiej części obrad plenarnych dr hab. prof. UP Grażyna Gunia omówiła mocne i słabe strony dotychczasowego dorobku logopedii jako dyscypliny naukowej, zawodu i kierunku studiów - w perspektywie wyzwań na miarę XXI wieku. W kolejnych wystąpieniach dr hab. prof. UMCS Tomasz Woźniak przedstawił wyniki i wnioski z badań dotyczących niepłynności mówienia u osób niepełnosprawnych intelektualnie, natomiast prof. dr hab. n. med. Grażyna Śmiech-Słomkowska oraz lek stom. Małgorzata Peruga (UM) podkreśliły znaczenie mięśni w budowie i czynnościach narządów jamy ustnej, w odniesieniu do pacjentów leczonych ortodontycznie. Podczas ostatniego referatu w sesji plenarnej dr hab. prof. UŁ Irena Jaros przybliżyła zagadnienie właściwej oceny indywidualnych cech wymowy o proweniencji dialektalnej, zarówno zgodnych z normą ortofoniczną, jak też uznawanych za fonetyczne błędy językowe. 
W sekcji A dr Ewa Gacka (UŁ) zaprezentowała teoretyczne i praktyczne wnioski dotyczące diagnozowania oraz usprawniania funkcji oddechowej w postępowaniu logopedycznym. Dr Anna Stefan (UŁ) zwróciła uwagę na coraz częściej diagnozowane zaburzenia adaptacyjne w stresie, dotyczące pacjentów o profilu osobowościowym „wrażliwcy”, u których stwierdza się dysfunkcje narządu głosu. Z kolei dr Monika Kaźmierczak (UŁ) omówiła typy oraz funkcję gestów fonicznych stosowanych w postępowaniu logopedycznym zarówno przez logopedów, rodziców/opiekunów, jak i pacjentów. Obrady w sekcji zakończyło wystąpienie mgr Aleksandry Jastrzębowskiej-Jasińskiej (APS), która - po przedstawieniu wyników własnych badań - zastanawiała się nad potrzebą wprowadzenia i stosowania superwizji przez logopedów.

W sekcji B dr hab. Renata Marciniak-Firadza (UŁ) przedstawiła kompetencje słowotwórcze dzieci na przykładzie kategorii nazw narzędzi, a dr Izabela Ejsmunt-Wieczorek (UŁ) ukazała sposoby tworzenia czasownikowych gniazd słowotwórczych przez dzieci w wieku przedszkolnym. Następnie dr Magdalena Olempska-Wysocka (UAM) omówiła zastosowanie modelu SCALE przy tworzeniu holistycznego obrazu możliwości słuchowych i komunikacyjnych dziecka z uszkodzonym słuchem oraz określaniu jego specjalnych potrzeb komunikacyjnych, natomiast dr Katarzyna Bieńkowska (APS) zaprezentowała wyniki badań gotowości szkolnej dzieci z wadą słuchu oraz wskazówki dotyczące dalszego rozwoju procesów rehabilitacyjnych dzieci z uszkodzonym narządem słuchu. Obrady w sekcji zakończył referat dr Marleny Kurowskiej (UW), która dokonała porównania zachowań (poza)językowych u dzieci z uszkodzeniami i/lub dysfunkcjami OUN, w zależności od podłoża zmian i ich lokalizacji.

W sekcji C dwa pierwsze referaty dotyczyły pacjentów z otępieniem - dr Renata Gliwa (UŁ) oceniła przydatność testów fluencji słownej w diagnozie różnych typów otępienia, a mgr Justyna Antczak-Kujawin (UŁ), na podstawie wyników autorskiego testu do badania sprawności leksykalno-semantycznej u osób z otępieniem, omówiła objawy trudności językowych związane z zaburzeniami struktury i znaczenia związków frazeologicznych. W kolejnych wystąpieniach mgr Justyna Sochacka (UŁ) scharakteryzowała mowę osiemdziesięcioośmioletniej pacjentki cierpiącej na rzadki neurologiczny zespół chorobowy, tj. zanik wieloukładowy, natomiast mgr Karina Wichurska (UŁ) zobrazowała trudności, z jakimi borykają się pacjenci cierpiący z powodu afazji sensoryczno-motorycznej oraz towarzyszących jej zaburzeń sfery poznawczej, motywacyjno-emocjonalnej i społecznej. Na zakończenie sesji mgr Dominika Kozłowska (WCO) omówiła znaczącą rolę onkologopedy w poprawie jakości życia pacjentów z coraz częściej diagnozowanymi nowotworami głowy i szyi.

Sekcję D zainaugurował referat dr hab. Katarzyny Jachimowskiej (UŁ) i mgr Agaty Koryckiej (UŁ) dotyczący negatywnych konsekwencji piercingu oralnego dla czynności prymarnych oraz wykonywania precyzyjnych ruchów artykulacyjnych. W kolejnych wystąpieniach dr Ewelina Zając (UŁ) ukazała wpływ zaburzeń mowy dzieci pięcio- i sześcioletnich na naukę czytania oraz pisania, mgr Karolina Stefaniak (UŁ) 
omówiła umiejętności kategoryzowania przez dzieci sześcioletnie, a mgr Mateusz Szurek (UŁ) zaprezentował doniesienia z przesiewowych badań mowy dzieci w wieku przedszkolnym.

Podejmowane tematy stały się przyczynkiem do ożywionych dyskusji oraz formułowania wniosków na przyszłość. Podczas podsumowania konferencji dr hab. prof. UŁ Danuta Pluta-Wojciechowska i dr hab. prof. UMCS Tomasz Woźniak podkreślili wartość takich spotkań konferencyjnych, wyrazili też przekonanie o dobrych perspektywach rozwoju polskiej logopedii. Po zakończeniu konferencji odbyły się równolegle trzy warsztaty, przeprowadzone przez: dr hab. prof. UŁ Danutę Plutę-Wojciechowską: Ocena ruchomości języka (m.in. wodniesieniu do wędzidełka języka) w aspekcie czynności prymarnych i artykulacji, dr n. med. Marzenę Mielczarek: Praktyczna analiza wyników testów audiologicznych u dzieci i dorostych oraz lek. stom. Agatę Sujecką-Brzóskę: Diagnozowanie wad narządu żucia i planowanie leczenia we wspótpracy ortodonty z logopedą.

Zajmujące referaty, ożywione dyskusje, inspirująca wymiana myśli i niezaspokojona jednodniowym spotkaniem żądza wiedzy każą przypuszczać, że kolejna konferencja z cyklu Logopedia wobec wyzwań i zagrożeń XXI wieku będzie równie interesująca. 